\title{
Evolution of entero-biliary fistula following gallstone ileus management
}

\author{
Peter M Neary, Joseph F Dowdall \\ Department of Vascular and General Surgery, Waterford Regional Hospital, Waterford, Ireland
}

Correspondence to Peter Neary, peterneary@hotmail.com

\section{DESCRIPTION}

A healthy 78-year-old man was admitted with a 3-day history of epigastric pain and bilious vomiting. Ultrasound revealed cholelithiasis with a normal calibre common bile duct. The patient subsequently underwent an upper gastrointestinal endoscopy which demonstrated a large duodenal defect consistent with an entero-biliary fistula (figure 1). Abdominal CT demonstrated small bowel dilatation (large arrow, figure 2), large calcifications within the small bowel and pneumobilia (small arrow, figure 2) consistent with gallstone ileus. The patient underwent a laparotomy and enterolithotomy. The choledocho-duodenal fistula was not disturbed. He had an unremarkable recovery. A repeat upper gastrointestinal endoscopy 4 months later demonstrated that the duodenal defect had completely healed (figure 3). Considerable controversy exists in the surgical literature about the appropriate management of choledocho-duodenal fistula at laparotomy for gallstone ileus. These images demonstrate for the first time, spontaneous healing of an entero-biliary fistula in a patient with gallstone ileus.

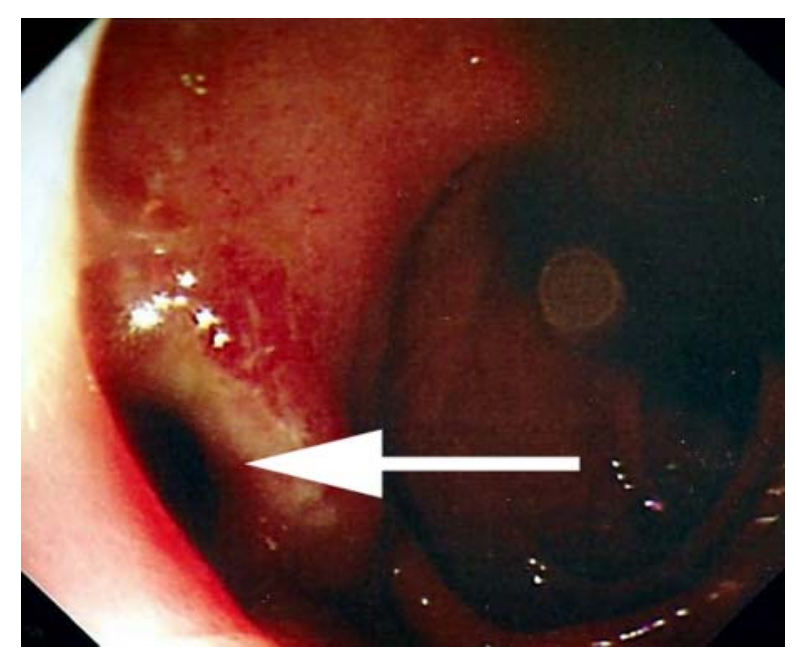

Figure 1 Entero-biliary fistula.

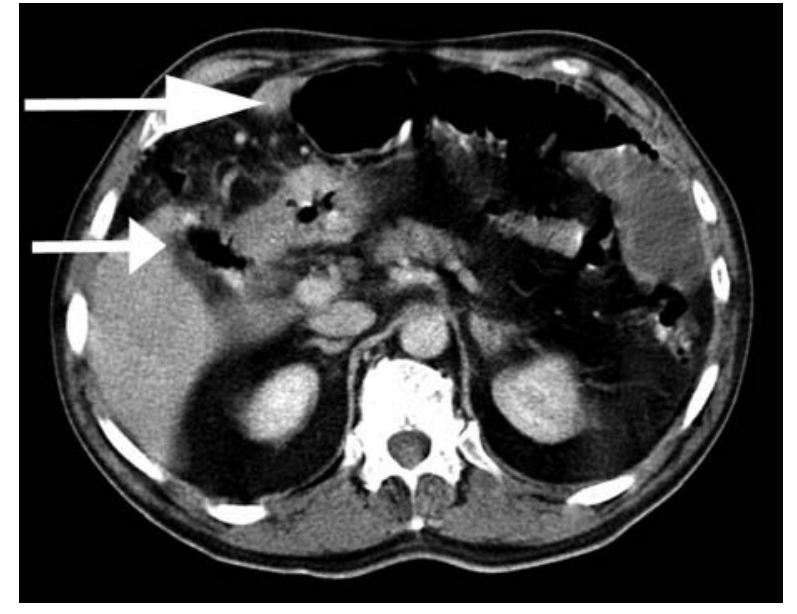

Figure 2 Pneumobilia and small bowel dilatation on CT.

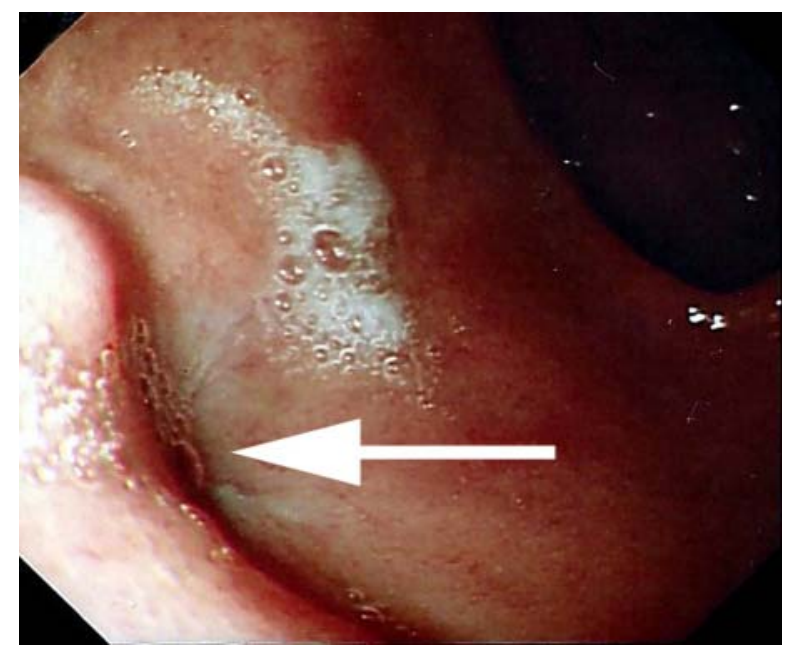

Figure 3 Healed entero-biliary fistula. 


\section{BMJ Case Reports}

Learning points

Competing interests None.

Patient consent Obtained.

- Spontaneous healing of an entero-biliary fistula in a patient with gallstone ileus can occur.

- An entero-biliary fistula can be successfully managed non-operatively.

This pdf has been created automatically from the final edited text and images.

Copyright 2012 BMJ Publishing Group. All rights reserved. For permission to reuse any of this content visit http://group.bmj.com/group/rights-licensing/permissions.

BMJ Case Report Fellows may re-use this article for personal use and teaching without any further permission.

Please cite this article as follows (you will need to access the article online to obtain the date of publication).

Neary PM, Dowdall JF. Evolution of entero-biliary fistula following gallstone ileus management. BMJ Case Reports 2012;10.1136/bcr-2012-006929, Published $X X X$

Become a Fellow of BMJ Case Reports today and you can:

- Submit as many cases as you like

- Enjoy fast sympathetic peer review and rapid publication of accepted articles

- Access all the published articles

- Re-use any of the published material for personal use and teaching without further permission

For information on Institutional Fellowships contact consortiasales@bmjgroup.com

Visit casereports.bmj.com for more articles like this and to become a Fellow 